\title{
Farmers' Perception of Soil Erosion Control Measures: Implications for Sustainable Development in Agriculture and Environment in South East, Nigeria
}

\author{
Simeon Okpoto Eze and Esther Etenmugonwa Osahon \\ Department of Rural Sociology and Extension, Michael Okpara University of Agriculture, Umudike, Umuahia PMB 7267, Abia State, \\ Nigeria
}

\begin{abstract}
The study investigated farmers' perception of soil erosion control measures and highlighted implications for sustainable development in agriculture and environment in southeast, Nigeria. Purposive, multistage and random sampling techniques were employed in selecting a sample size of two hundred and forty (240) respondents. Structured interview schedule was used for data collection, while percentages, mean ratings and factor analysis techniques were employed for analysis. The findings show that majority (64.6\%) of farmers were within the ages of 40-59, while majority (67.9\%) had either FSLC or WASCE/SSCE/GCE/OL qualifications. The farmers reported that the major soil erosion control measures used were strip cropping $(\mathrm{M}=4.8)$ and making of ridges against slopes $(M=4.7)$. The study reported that poor group affinity, inadequate institutional support and inadequate technical knowhow were constraints to soil erosion control in southeast, Nigeria. The study highlighted implications for sustainable development in agriculture and environment on organizational overhaul in extension, participatory extension policy on farmers groups and institutional re-orientation and synergy between Universities, Agricultural Development Programme (ADP), Ministry of Agriculture (MOA) and Local Government Councils. In conclusion, success in soil erosion control and sustainable development in agriculture and environment in southeast, Nigeria depends on the extent issues raised and implications highlighted can be addressed. The study recommends improved funding support to extension, participatory extension training and contacts with farmers' groups and groups' resources management.
\end{abstract}

Key words: Farmers, erosion control, sustainable development, Nigeria.

\section{Introduction}

Sustainable development in agriculture and environment are crucial millennium development goals (MDGs) in Nigeria. Sustainable development in agriculture in Nigeria has been threatened by environmental degradation arising from soil erosion menace [1]. Earlier research reports by Ofomata, Okoye and FAO [2-4] have identified soil erosion control measures as crucial towards improving environmental quality, agricultural productivity and reducing poverty as well as hunger worldwide. Both Obiefuna and Emebiri, Igbokwe and Onu [5,6] view that more than $50 \%$ of erosion menace as a serious

Corresponding author: Simeon Okpoto Eze, B.Sc, M.Sc., $\mathrm{Ph} . \mathrm{D}$., research field: agricultural extension administration. threat to ecological balance and agricultural development occurs in south east Nigeria. Moreover, previous studies on soil erosion have concentrated on issues relating to concepts and damages of erosion [7] and socio-economic impact of erosion on farmers [8]. Other studies have considered farmers' perception and response to erosion [9], farmers' response and adoption of investment measures [1] and erosion problems on food production [10]. However, there is paucity of information on farmers' perception of erosion control measures as major stakeholders in sustainable development in agriculture and environment in Southeast, Nigeria.

Farmers' perception is based on their socio-economic conditions. This scenario constitutes a critical measure of comprehension among farmers 

Agriculture and Environment in South East, Nigeria

geared towards organized and meaningful interpretation of any agricultural and related issues on environment. Farmers' perception constitutes effective approach towards the right of people to self-determination and involvement of felt needs for sustainable development in southeast, Nigeria. Desirable participation among farmers hinge on their perception of soil erosion control measures with practices compatible with their existing knowledge and socio-economic conditions. This raises the following pertinent questions. What are the socio-economic characteristics of farmers in Southeast, Nigeria? What is the perception of farmers on soil erosion control measures under the ADPs? What are constraints to farmers' soil erosion control measures? What specific lessons would be learned from farmers' perception of soil erosion control measures that could serve as useful implications for sustainable development in agriculture and environment in southeast, Nigeria?

The overall purpose of this study was to investigate farmers' perception of soil erosion control measures and highlight implications for sustainable development in agriculture and environment in southeast, Nigeria. Specifically, the objectives were to: describe socio-economic characteristics of farmers in southeast, Nigeria; ascertain farmers knowledge level of measures employed in soil erosion control; identify constraints to involving farmers' perception in soil erosion control and highlight implications for sustainable development in Agriculture and environment in Southeast, Nigeria.

\section{Materials and Methods}

The study was carried out in southeast agricultural zone of Nigeria. The zone is made up of four states namely: Abia, Anambra, Ebonyi, Enugu and Imo. Both farmers served by the states ADPs as contact farmers and non-contact farmers constituted the population for the study. Purposive, multistage and random sampling techniques were employed in data collection. Three states namely, Abia, Anambra, and Imo were purposively selected because of proximity and intensity of agricultural production as well as intensity of soil erosion in the states. Two local government areas were purposively selected from each of the states. From each of the LGAs involved, 2 communities and from each of the communities, 2 villages were randomly selected, while from each of the villages involved, 15 farmers were randomly selected. Thus a total of two hundred and forty (240) respondents randomly selected constituted sample size for the study. A structured interview schedule for farmers was employed for data collection, while analytical tools such as frequency counts, percentages, mean scores and factor analysis techniques were adopted. The exploratory factor analysis technique using the principal factor model with interaction and varimax rotation was adopted. The factor loading under each constraint (beta weight) represent a correlation of the variables (constraint areas) to the identified constraints factors and has the same interpretation as any correlation co-efficient. Kaiser's criterion using factor loading of 0.30 and above in naming and interpreting the factors and constraint variables was adopted $[11,12]$.

\section{Results and Discussion}

\subsection{Socio-economic Characteristics of Farmers}

Data in Table 1 show that majority (64.6\%) of farmers were within the ages of 40-59 years, while majority $(75.8 \%)$ were males. The study indicates that most farmers covered were adults within the active ages which could predispose them to be knowledgeable in soil erosion activities of the ADPs. However the ADPs had limited coverage of women $(24.2 \%)$ and youths (30.0\%). Studies by Mbanefo, Uwakah et al. [13, 14] have recommended that any effort on agricultural development including soil erosion control must involve meaningful population of women as crucial labour force to achieve the desired objectives. 
Table 1 Percentage distribution of respondents according to socio-economic characteristics.

\begin{tabular}{|c|c|c|}
\hline Socio-economic characteristics & Frequency $(\mathrm{n}=240)$ & Percentages $(\%)$ \\
\hline$\overline{\text { Age (yrs) } \leq 29}$ & 44 & 18.3 \\
\hline $30-39$ & 41 & 17.1 \\
\hline $40-49$ & 91 & 37.9 \\
\hline $50-59$ & 64 & 26.7 \\
\hline 60 years and above & 10 & 4.2 \\
\hline \multicolumn{3}{|l|}{ Gender: } \\
\hline Male & 182 & 75.8 \\
\hline Female & 58 & 24.2 \\
\hline \multicolumn{3}{|l|}{ Marital status: } \\
\hline Married & 115 & 47.9 \\
\hline Single & 72 & 30.0 \\
\hline Widowed & 53 & 22.1 \\
\hline Household size $(\mathrm{No}): \leq 5$ & 74 & 30.8 \\
\hline $6-10$ & 94 & 39.2 \\
\hline $11-15$ & 52 & 21.7 \\
\hline 16 and above & 20 & 8.3 \\
\hline Farm holdings $(\mathrm{Ha}): \leq 0.5$ & 37 & 15.4 \\
\hline $0.6-1$ & 83 & 34.6 \\
\hline $1.5-2$ & 74 & 30.8 \\
\hline $2.5-3$ & 31 & 12.9 \\
\hline 3.5 and above & 15 & 6.3 \\
\hline Level of formal education: No formal education & 20 & 8.3 \\
\hline FSLC & 69 & 37.1 \\
\hline WASC/SSCE/GCE O/L & 75 & 30.8 \\
\hline OND/NCE & 37 & 15.4 \\
\hline $\mathrm{HND} / \mathrm{BA} / \mathrm{BED} / \mathrm{BSC}$ & 28 & 11.7 \\
\hline MSC/MA/MED/MBA and above & 16 & 6.7 \\
\hline Primary occupation: Full time farming & 127 & 52.9 \\
\hline Trading & 54 & 22.5 \\
\hline Artisan & 23 & 9.6 \\
\hline Civil service & 35 & 15.0 \\
\hline Farming experience (yrs): $\leq 5$ & 22 & 9.2 \\
\hline $6-10$ & 43 & 17.9 \\
\hline $11-15$ & 45 & 18.8 \\
\hline $16-20$ & 55 & 22.9 \\
\hline $21-25$ & 42 & 17.5 \\
\hline $26 \mathrm{yrs}$ and above & 33 & 13.8 \\
\hline Membership of social organizations: Chairman & 16 & 6.7 \\
\hline Secretary & 21 & 8.8 \\
\hline Financial Secretary & 18 & 7.5 \\
\hline Provost & 21 & 8.8 \\
\hline Ordinary member & 164 & 68.3 \\
\hline Estimated Annual income $(\mathrm{N}): \leq 50,000.00$ & 25 & 10.4 \\
\hline $51,000.00-100,000.00$ & 43 & 17.9 \\
\hline $101,000.00-150,000.00$ & 66 & 27.5 \\
\hline $151,000.00-200,000.00$ & 83 & 34.6 \\
\hline $201,000.00$ and above & 23 & 9.6 \\
\hline
\end{tabular}

Field survey, 2014.

About $47.9 \%$ of the farmers were married, $60.9 \%$ had household size of 6-15 members, while majority (65.4\%) have farm holdings of $0.6-2$ hectares. The study indicates that most farmers were married and are small holder farmers. However, the marital statuses and household sizes are related socio-economic variables which would serve as driving forces towards participation in soil erosion activities needed to meet household agricultural production needs. Examined against the intensity of labour requirement of soil erosion control, the study indicates inadequate family labour for sustainable development in agriculture and 

Agriculture and Environment in South East, Nigeria

environment. The findings of the study agrees with Asiabaka [15] who recommended group participation as a critical element of a viable measure needed for development initiatives and food security worldwide Majority $(67.9 \%)$ of the farmers have either FSLC or WASC/SSCE/O?L qualifications, while 52.9 percent were full time farmers. The study indicates inadequate level of education among the farmers under the ADPs. This scenario could influence negatively group participation and comprehension of relevant information on soil erosion control among farmers. The study therefore, agrees with Blum and Madukwe $[16,17]$ who reported education as a facilitating factor in any agricultural enterprise including those related to soil erosion control. Thus the higher the educational attainment among farmers, the more favourable their disposition is towards group cohesion and participation in modern soil erosion activities for sustainable development in Agriculture and environment in Nigeria. Majority $(62.1 \%)$ of the farmers reported estimated annual income of $\mathrm{N}$ 101,000.00-N 200,000.00. Estimated annual income of a farmers' is the income from his farm enterprise which is the excess revenue and value of household output over cost [18]. Examined against the backdrop of this study, farmers in southeast, Nigeria seem to have low annual income. This scenario could make the farmers to rely on personal savings for capital intensive farm investment and land resource management such as soil erosion control. Relying on personal savings for soil erosion control could delay the process of sustainable development in agriculture and environment in Southeast, Nigeria.

\subsection{Farmers' Knowledge Levels on Soil Erosion Control Measures}

Data in Table 2 show that the farmers reported appreciable awareness in construction of diversion ditch (54.2\%), mixed cropping (51.3\%) and strip Cropping (50.0\%), tie ridging $(48.8 \%)$ and sod water ways $(47.1 \%)$. These soil erosion control measures no doubt, could be associated with age long traditional soil/land management practices of the farmers in Southeast, Nigeria. This scenario underscores the need

Table 2 Farmers' perceived mean knowledge level on soil erosion control measures in southeast, Nigeria.

\begin{tabular}{lll}
\hline Soil erosion control issues & Percentages $(\%)(\mathrm{n}=240)$ & Knowledge mean $($ Max $=5)$ \\
\hline Strip cropping & $130(54.2)$ & 4.8 \\
Wind break & $98(40.8)$ & 3.5 \\
Use of organic manure & $87(36.3)$ & 2.7 \\
Gross strip & $101(42.1)$ & 2.9 \\
Stone terrace & $72(30.0)$ & 1.6 \\
Contouring & $65(27.1)$ & 2.1 \\
Mixed cropping & $123(51.3)$ & 3.8 \\
Tie ridging & $117(48.8)$ & 3.9 \\
Mulching & $97(40.4)$ & 1.1 \\
Graded bond & $105(43.8)$ & 3.2 \\
Construction of diversion ditch & $75(31.3)$ & 3.6 \\
Construction of ridges across slopes & $120(50.0)$ & 4.7 \\
Sod water ways & $103(47.1)$ & 3.8 \\
Concrete bonds & $94(39.2)$ & 2.3 \\
Land smothering & $31(12.9)$ & 1.8 \\
Earth dam & $83(34.6)$ & 3.3 \\
Shifting cultivation & $92(38.3)$ & 3.4 \\
Strip terracing & $56(23.3)$ & 2.0 \\
Group mean & & 2.9 \\
\hline Fidd survey 2014. & &
\end{tabular}


for soil erosion control activities under the ADPs to be anchored on farmers' perception of the existing land management practices in order to stimulate desirable participation among the farmers.

\section{Figures in parenthesis represent percentages:}

It could be deduced from this result that these measures which farmers have good knowledge of are possibly related to their traditional land management practices and soil erosion control techniques. Moreover, with the group mean of 2.9 indicated in this study, it is obvious that most farmers lack appreciable knowledge of modern soil erosion measures. This study agrees with Igbokwe and Okoye [19], who reported that farmers in Nigeria are knowledgeable on soil erosion control practices that have relationship with soil management techniques common in their areas. This situation implicates the role of ADPs to involve farmers' perception of indigenous practices in order to enhance comprehension and stimulate participation among farmers for effective soil erosion control.

\subsection{Farmers' Perceived Constraints to Soil Erosion Measures in Southeast, Nigeria}

Data in Table 3 show the varimax rotated factors perceived by farmers as constraints to soil erosion control measures. Based on specific issues and items loading three major factors were extracted namely; factor 1, poor group affinity (factor 1), lack of institutional support (factor 2) and, inadequate technical knowhow (factor 3). Some specific issues which loaded high under poor group affinity include, lack of good rural leadership (0.67), inadequate co-operation among members of social groups (0-54) and intra-community conflicts (0.45). Good rural leadership is fundamental to peace and harmony in any community. Good leadership propels mutual co-existence in social groups and this could stimulate

Table 3 Factor analysis of farmers perceived constraints on soil erosion control under the ADPs.

\begin{tabular}{llll}
\hline Constraint variables & $\begin{array}{l}\text { Factor I Poor Group Factor 2 lack of } \\
\text { affinity }\end{array}$ & $\begin{array}{l}\text { Factor 3 Inadequate } \\
\text { Technical Know } \\
\text { Institutional Support }\end{array}$ \\
\hline Poor government land policy & 0.32 & 0.14 & 0.06 \\
Inadequate fund to social groups & -0.22 & 0.42 & -0.03 \\
Lack of information on soil erosion control & 0.26 & 0.02 & 0.41 \\
Intra-community conflicts & 0.48 & 0.06 & -0.28 \\
Inadequate research extension farmer linkages & -0.34 & 0.30 & 0.18 \\
Lack of good rural leadership & 0.67 & 0.01 & -0.14 \\
Inadequate support to ADP extension services & 0.12 & 0.39 & -0.01 \\
Inadequate co-operation among members of social organizations & 0.54 & 0.20 & 0.06 \\
Unavailability of social groups for extension training & 0.45 & 0.03 & 0.19 \\
Farmers' apathy towards soil erosion control & 0.38 & 0.09 & 0.32 \\
Inadequate extension contacts & 0.28 & -0.30 & 0.19 \\
Non-recognition of social groups on the part of govt. & 0.20 & 0.44 & 0.50 \\
Land management problems & 0.13 & -0.07 & 0.11 \\
Insensitivity of farmers towards group activities & 0.41 & -0.02 & -0.06 \\
Lack of credit facilities & 0.24 & 0.43 & 0.10 \\
Low empathy towards self-help soil erosion control & 0.33 & 0.02 & -0.40 \\
Lack of rural infrastructure & 0.03 & 0.53 & 0.10 \\
Incompatibility of ADP with indigenous process & 0.06 & 0.46 & 0.36 \\
Incomprehension Among farmers & 0.04 & -0.32 & 0.49 \\
Multiple local cropping pattern among farmers & 0.05 & 0.03 & 0.15 \\
Varying topography of farm environment & -0.13 & 0.45 & \\
\hline
\end{tabular}

Field survey 2014. 
farmers for group approach to soil erosion control. Equally, intra-community conflict could be as a result of absence of co-operation which can be blamed on bad rural leadership all of which aggravate poor group affinity.

Lack of institutional support depicts the scenario of weakness on the part of relevant institutions in providing enabling environment and needed facilities to ADP extension services in order to enhance soil erosion control among farmers. According to Negedu [20], the effectiveness of agricultural extension depends on the extent it is supported and strengthened to serve farmers. Some specific issues which amplified lack of institutional support include; lack of rural infrastructure (0.53), incompatibility of ADPs with indigenous process (0.46) and varying topography of farm environment (0.43). Lack of rural infrastructures worsens the varying topography of farm environment and this scenario could affect negatively the compatibility of the ADPs with indigenous process. This study therefore corroborates with Eze [21] who identified inadequate rural infrastructure as a constraint factor limiting contact with farmers in the southeast, Nigeria.

Factor 3 indicates inadequate technical knowhow. Some specific issues which loaded high under inadequate technical knowhow include: land management problems (0.50), multiple local cropping pattern among farmers (0.49) and lack of information on soil erosion control (0.41). The multiple local cropping patterns among farmers could be blamed on land management problems and this scenario is worsened by lack of information on soil erosion control which aggravate inadequate technical knowhow. This study therefore, agrees with Alimi [18] who identified land as a critical resource in agricultural development and noted land ownership as fundamental to land management. Consequent upon the foregoing, land management could exert significant influence on sustainable development in agriculture and environment in southeast, Nigeria.
Moreover multiple local cropping pattern among farmers has been associated with degradation and soil erosion in Nigeria [22].

\subsection{Implications for Sustainable Development in Agriculture and Environment in Southeast, Nigeria}

There could be a consensus that various government administrations in Nigeria have made conscientious efforts towards sustainable development in agriculture and environment needed to attain food security and MDGs. However, the extent of goals attainment is doubtful in terms of meaningful synergy among relevant institutions and participation among farmers in addressing severe problems of soil erosion based on farmers' perception of land resource management as a critical aspect of agricultural production. The desirable land resource management has been ravaged by soil erosion occasioned by prevalent ecological features of steep slopes and sandy feralitic soil resulting in loss of essential arable surface, nutrients, and low yield. This study was anchored on farmers' perception as fundamental in enhancing participation in soil erosion control and achievement of sustainable development in agriculture and environment. Hence three constraints namely poor group affinity, lack of institutional support and inadequate technical knowhow were identified as limiting to participation among farmers in soil erosion control under the ADPs in Southeast, Nigeria. Farmers' perception has implications for participation and adoption of soil erosion control measures. The envisaged participation has implications for farmers to build group affinity and strengthen group participation in soil erosion control measures in southeast, Nigeria. This scenario demands conscientious efforts on the part of government to harmonize soil erosion control activities in existing and emerging social groups by stimulating them in group activities.

The envisaged efforts of the government have implications to government in facilitating synergy and linkages between relevant institutions with the ADPs. 
This requires improvement in budgetary allocation in order to elicit necessary agricultural research and extension training in soil erosion control under the ADPs. The envisaged improvement in budgetary allocation demands emphasis on critical infrastructure, credit and support funding in order to make extension training and delivery in soil erosion control more efficient under the ADPs as grassroots oriented organization. Moreover, the desirable linkages and relationship have implications for institutional re-orientation among relevant institutions to improve agricultural production and environmental conservation using the ADPs as the implementing arm. The situation demands concentration of efforts among relevant institutions on developing relevant technologies on soil erosion and primary production as well as foster interest with farmers as stakeholders through strong synergy with the ADPs. The envisaged synergy involves organizational overhaul in the ADPs to involve effective participatory extension delivery policy. The envisaged participatory extension policy also involves necessary extension methodology to narrow the communication gap between research in developing soil erosion control techniques and farmers who are the recipient of soil erosion hazards.

Again the envisaged extension methodology and participatory policy demand the ADPs provide training opportunity to improve staff skills and knowhow needed to re-orientate their attitudes towards natural land resources management based on farmers' perception. Moreover the envisaged improvement in staff skills under the ADP has implications for harmonization and co-operation between the ADPs and existing as well as emerging social organizations. The envisaged harmonization and co-operation has implications to the ADP to orientate and focus extension contacts on perceived erosion control measures among farmers groups and group mobilization for land resource management. The desirable groups' mobilization in soil erosion control and land resource management has implications to the ADPs to involve group dynamics and indigenous process. The envisaged involvement of group dynamics and indigenous process has implications for the ADPs in working with rural leadership and organizations to overtly overhaul and restructure them. This scenario will serve as strategy to improve group leadership and skills as well as the farmers' knowhow to make them truly participate in soil erosion control measures. Moreover the restructuring process in social organizations has implications for the farmers strengthen affinity to work in groups and involve self-help efforts in soil erosion control under the ADPs.

\section{Conclusions}

The study investigated farmers' perception of soil erosion control measures and highlighted implications for sustainable development in agriculture and environments in southeast, Nigeria. The study was based on the premise that soil erosion control is fundamental to environmental sustainability and attainment of MDGs. Results of the study indicate that the ADPs in the southeast, Nigeria adapt strategies to control soil erosion devastation and loss of essential surface, nutrients, removal of arable soil and low agricultural production. However, the enormity of soil erosion devastation and attendant low agricultural production are blamable on lack of proper considerations of farmers' perception as major stakeholders in the agriculture sub-sector. The scenario is attributed to critical constraints namely, poor group affinity, lack of institutional support and inadequate technical knowhow. The constraints were highlighted to have implications for greater farmers' groups affinity and food security in Nigeria. These implications were highlighted on involvement of social dynamics and rural leadership, institutional re-orientation and linkages as well as organizational overhaul and improved government budgetary allocation and support to the ADPs. Success in soil erosion control among farmers under the southeast 

Agriculture and Environment in South East, Nigeria

ADPs depend largely on extent issues raised and challenges thereof highlighted can be addressed. These implications constitute serious issues to consider for effective soil erosion control and sustainable development in agriculture and environment in southeast, Nigeria. The study recommends synergy between the MOA, research institutes and universities with the ADPs as well as extension training in harmonized social groups.

\section{References}

[1] Onu, D. O. 2013. "Farm Level Analysis of Investment Behaviours in Soil Conservation and Erosion Control Practices in the Ecologically Vulnerable Communities in Southeast, Nigeria." Agriculture and Biology Journal of North America 4 (4): 441-58.

[2] Ofomata, G. E. K. 1987. "Soil Erosion in Nigeria: the Views of A Geomorphologist." University of Nigeria Inaugural lecture series; No 7.

[3] Okoye, C. U. 1995. Soil Erosion Control Technology Systems Among Small Scale Farmers in Anambra State, Nigeria. M.Sc. Thesis; Department of Agricultural Extension, University of Nigeria, Nsukka, Nigeria.

[4] Food and Agriculture Organization (FAO) 2006. Eradicating World Hunger-Taking Stock ten years after the World Food Summit: The state of Food Insecurity in the World; FAO, Rome.

[5] Igbokwe, J. I. 2004. Gully erosion mapping/monitoring in parts of South-eastern Nigeria; Paper presented at the National Workshop on Satellite remote Sensueng and GIS: a solution to sustainable national development challenges; Abuja, June, 15-7.

[6] Onu, D. O. 2006. "Socioeconomic Factors Influencing Farmers Adoption of Alloy Farming Technologies under Intensified Agriculture in Imo State, Nigeria." the Philippine Agricultural Scientist 89 (2): 521-43.

[7] Barker, M. M., Govers, G., Jones, R., and Rounsevell, R. 2005. The Effect of Soil Erosion on Agricultural Productivity; Geographical Research Abstracts, Vol. 7, 006955 European Geosciences Unions; SRef-ID, 1607-79124 gra/EGUO5-A-00695.

[8] Abegunde, Albert, A., Adeyinka, Samson, A., Okwuri, Peter O., and Oluodo, Olifunmilayo, A. 2006. An Assessment of the Socio-Economic Impact of Soil Erosion in South-Eastern in South-Eastern Nigeria. Shaping the Change; XXIIIFIG Congress Ngurich, Germany, pp. 1-15.

[9] Yusuf, M. B., and Ray, H. H. 2011. "Farmers' Perception and Response to Soil Erosion in Zing Local Government
Area of Taraba State, Nigeria." Ethiopian Journal of Environmental Studies and Management 4 (1): 93-8.

[10] David Pimentel, and Michael Burgess 2013. Open Access Agriculture; available at www.mdpi.com/journal/agriculture. retreived 10/07/2015. pp. 443-63.

[11] Child, D. 1978. The Essentials of factor Analysis; New York, Holt Rinehart and wilstarm Ltd.

[12] Ogunfiditimi, I. J. O. 1979. "Construction of Five Factor Attitude for Evolution of the Food for Work Programme." Journal of Social Psychology 187: 25-33.

[13] Mbanefo, M. 1990. Women: A potent Labour force in grassroot development In: Osita M. Ogbu; Benji O. Oyeyinka and Hasa M. Mlawa (eds.); Technology and practice in Africa; IDRC, Otawa, Canada; 346 pp.

[14] Uwakah, C. T., Uwaegbute, A. C., and Madukwe, M. C. 1991. The role of women as farmers in Eastern Nigeria; Issues in Agricultural Development Winrock International Institute for Africas Development.

[15] Asiabaka, C. C. 2008. The need for Agricultural Extension policy in National Development; A keynote Address; Developing Agricultural Extension Policy for Nigeria; proceedings of the 13th Annual National Conference of the Agricultural Extension society of Nigeria; April; Pp 1-16.

[16] Blum, A. 1991. What can be learned from a comparison of the Agricultural knowledge system? The case of the Netherlands and Israel, Agricultural Ecosystem and Environment 33: 325-39.

[17] Madukwe, M. C. 1995. Agricultural extension systems and strategies in Nigeria's rural development; In: E. C. Eboh, C. U. Okoye, and D. Ayichi (eds); Rural Development in Nigeria: concepts, processes and prospects; Enugu Auto-century publishing company; Pp.265-73.

[18] Alimi, T. 1991. "Influence of the Socio-economic Characteristic of Small Holder Farmers on Resources Availability in Farming; Rural Development in Nigeria." Journal of the Federal Department of Agriculture 4 (1): 1-5; Abuja, Nigeria, June.

[19] Igbokwe, E. M., and Okoye, T. K. 2000. Knowledge and perception of soil and water conservation methods among practicing and potential Extension Agents; A preliminary survey; Agricultural extension and poverty Alleviation in Nigeria; Proceedings of the Sixth Annual National Conference of the Agricultural Extension Society of Nigeria; April pp. 124-30.

[20] Negedu, S. 2007. Keynote Address, Agricultural Extension and the Millennium Development Goals (MDGs); proceedings of the 12th Annual National Conference of the Agricultural Extension System of Nigeria; p.1-2. 

Agriculture and Environment in South East, Nigeria

[21] Eze, S. O. 2000. "Factors Limiting Infrastructural Development and Extensioncontacts in Farming Communities in South-eastern Nigeria." Journal of Agri-Business and rural Development 2: 103-9. University of Uyo; Akwa Ibom State.

[22] Daudu, C. K., Onyibe, J. E., Jubrin, J. M., and Adegbehin, J. O. 1999. Refocusing land Management Technology on Farmers Problems and Capabilities; A Conceptual Framework for Extension Intervention; The Nigerian Journal of Agricultural Extension 12 (2).

[23] Madukwe, M. C. 1996. Restructuring field agricultural extension services in Nigeria: issues and options; In S. Fola Adedoyin and J. O. Y. Aihonsu (eds); Sustainable Development in Rural Nigeria; proceedings of the Eight Annual Conference of the Nigerian Rural Sociological Association; Ago-Iwoye; Ogun State University; pp. 314-20.

[24] Okafor, F. C. 1991. Population Pressure; agricultural change and environmental Consequences in South Eastern Nigeria; social science research council; Joint Committee on African agriculture; Working paper No. 3; New York; 34pp. 